\title{
Fluvial development of the Lower Rhine Basin during the late Tertiary and early Quaternary
}

\author{
Wolfgang Boenigk \\ Geologisches Institut, Universität Köln, 5000 Köln, Germany \\ Correspondence: $\quad$ Frank Preusser (frank.preusser@geologie.uni-freiburg.de) \\ Relevant dates: $\quad$ Published: 17 December 2021
}

How to cite: $\quad$ Boenigk, W.: Fluvial development of the Lower Rhine Basin during the late Tertiary and early Quaternary, DEUQUA Spec. Pub., 3, 125-131, https://doi.org/10.5194/deuquasp-3-125-2021, 2021.

Special issue statement. This article is part of a special issue published on the occasion of the 70th anniversary of $E \& G$ Quaternary Science Journal (EGQSJ). The special issue celebrates the journal's notable contribution to Quaternary research by revisiting selected milestone articles published in the long history of EGQSJ. The German Quaternary Association (DEUQUA) presents translations of the originals and critical appraisals of their impact in tandem anniversary issues of DEUQUASP and EGQSJ, respectively.

Original article: https://doi.org/10.3285/eg.28.1.01

Tribute: https://doi.org/10.5194/egqsj-70-2512021

Translators: Clare Bamford, Frank Preusser, and Henrik Rother

\footnotetext{
Abstract. Sedimentary and petrographic examinations of the strata overlying brown coal formations in the Lower Rhine Bay document deposition in a coastal environment during the Miocene and Pliocene. Small spatial changes in facies and fluctuation between humid and semiarid climatic conditions led to different types of sediments. Significant relative movements of the sea level within the Lower Rhine Basin are expressed in the rock record by erosional unconformities. During the Pleistocene, sedimentation was dominated by fluvial deposition. The combination of tectonic movement and climatic changes determined the alternation between erosion and sedimentation, and the change in the petrographic composition of the sediments.
}

\section{Introduction}

This article gives an overview of the spatial and temporal development of sedimentation in the Lower Rhine Basin, an area of subsidence. It is based on a detailed stratigraphic classification of the late Tertiary and early Quaternary sediments developed using sedimentological and sedimentarypetrographical methods (Boenigk, 1978a, b).

The fluvial development of the Lower Rhine Basin essentially took place from the lower Miocene until today. Older fluvial deposits are recorded from the lower Oligocene in the marginal areas of the Lower Rhine Basin (Kurtz, 1926, 1932; Sindowski, 1939) and through a few boreholes also in central areas. These strata are still not well documented. They mark the beginning of the development of the Lower Rhine Basin as an area of subsidence.

Due to the subsequent strong subsidence in this area, large marine advances occurred from the middle Oligocene onwards. In the upper Oligocene, the sea reached its greatest extent. It covered the entire basin and reached as far as the peneplain of the northern Eifel in the south and the "Bergische Randhöhen"1 in the east.

Subsequently, the sea retreated further to the north and northwest, episodically interrupted by small transgressions, while deposition in the Lower Rhine Basin increasingly shifted towards a fluvial-lacustrine facies. This marked the beginning of the development of the Lower Rhine Basin as a fluvial landscape, which continues until today. This fluvial

\footnotetext{
${ }^{1} \mathrm{TN}$ : the margin of the midlands of Palaeozoic age.
} 
development can be divided into two major periods (Fig. 1). During the older period, the southern Lower Rhine Basin was predominantly a deltaic environment with the shoreline situated approximately north of the "Jackerather Horst" 2 . This facies distribution prevailed during the Miocene and Pliocene (Boenigk, 1978b).

During the Pleistocene, the entirety of the Lower Rhine Basin was dominated by fluvial processes across a river landscape. The coastline was located much further to the north than previously, thereby roughly corresponding to its present-day position. Information on sedimentation in the Lower Rhine Basin during the Pleistocene is given by Breddin (1955) and Quitzow (1956).

\section{Late Tertiary}

While during the Miocene and Pliocene the facies was generally of a coastal depositional type (delta), the mode of sedimentation was essentially controlled by multiple climatic changes from humid to semi-arid conditions. The varying rates of subsidence of the entire basin or individual tectonic blocks within the basin led to several erosional phases (Boenigk, 1978b), represented as gaps in the stratigraphic record with no information on the climate and river history.

The preserved sedimentary sequence in the basin imply the following development: A first fluvial influence is recorded in the lower Miocene main lignite bed as seen in the Frechen open cast mine. Based on the petrographic composition of these sediments (Fig. 1), the gravel fraction was sourced from the fringes of the Lower Rhine Basin. The sand fraction, on the other hand, indicates an input from the Upper Rhine Graben (Boenigk, 1976). Sedimentological observations show that these deposits accumulated as a deltaic facies. These units are concordantly overlain by the main lignite bed, which is widespread in the entire southern and central part of the basin, while the northern portion of the basin was paralic as evidenced by the interbedding of terrestrial and marine sands (Breddin, 1932). Fluvial supply of sediment was low at this time and limited to the outermost margins of the basin.

During the following period of the Inden strata ("Indener Schichten"), clastic delta sedimentation re-started in the eastern part of the basin, as previously recorded in units stratigraphically underlying the main lignite bed (Figs. 1, 2). Towards the top of this sequence a more distally sourced component is increasingly observed within the gravel fraction. These sediments are separated out from the actual Inden strata as so-called transitional layers to the main gravel series (Boenigk, 1978b). The clastic sedimentation of the Inden strata and the deposition of the transitional strata were interrupted repeatedly by prolonged and widespread lagoonal phases and periods of subaerial soil formation, indicating a break in the supply of material.

\footnotetext{
${ }^{2} \mathrm{TN}$ : an uplifted block in the centre of the basin.
}

In the west of the Lower Rhine Basin, on the other hand, peat formation continued during this time in the upper lignite beds and deposits of marine coastal facies can be recognised in the clastic intermediates, in addition to terrestrial influences. A marine transgression across the Rur Block reached into the southwestern Lower Rhine Basin.

The climate at the time of peat formation associated with the main lignite bed is considered to have been tropical to subtropical (Weyland, 1934) and exclusively subtropical for the upper lignite bed (von der Brelie, 1968). The overlying coarse clastic sediments, on the other hand, indicate a dry, semi-arid climate leading to the widespread but periodic delivery of debris.

A subsequent interruption of sedimentation in the Lower Rhine Basin is marked by a weathering horizon. An associated decomposition and consequent lack of the less heavy minerals within these sediments can also be observed. Even the overlying sediments of the Main Gravel Series ("Hauptkies-Serie") show a depleted heavy mineral spectrum. Therefore, one can expect a widespread and intense weathering phase causing the depletion of the heavy mineral spectrum. This is the most prominent weathering horizon in the entire stratigraphic sequence of the Lower Rhine Basin, and it is therefore correlated to the lateritic soil formation at "Schwerfen" (Boenigk and Brinkmann, 1976) and at the "Vogelsberg" 3 implying a contemporaneous age. Thus, a warm alternating wet climate is assumed for this standstill phase in the sedimentation at the end of the Miocene.

The overlying coarse clastic sediments are predominantly of a deltaic origin. They are distributed throughout the Lower Rhine Basin and are termed as the Main Gravel Series, and dated to the lower Pliocene (von der Brelie, 1959). The source of the gravels and sand, comprising mainly material from the River Moselle area (Fig. 2), was a precursor fluvial system of the River Rhine. Typically, these sediments include siliceous oolite formations. In the west of the Lower Rhine Basin, the River Meuse also supplied material into the basin.

During this time, the fluvial facies extended at times far into the Lower Rhine lowlands, but for large periods the coast was not much further north than during the deposition of the Inden strata, as evidenced by prominent tidally influenced sediments in the Fortuna open cast mine.

The climate is interpreted to have been semi-arid for the time of the accumulation of the Main Gravel Series, as large amounts of coarse clastic materials were transported into the basin, at least partly via sheet flow debris transport. Once in the basin the sediments were frequently subaqueously reworked and redeposited. The gravel is extraordinarily coarse in the south of the basin still carrying numerous cobbles as far as to the Frechen open cast mine. Further north, the grain size decreases very rapidly to a sand facies with thin-layered gravel intercalations.

\footnotetext{
${ }^{3} \mathrm{TN}$ : this refers to an urban district in the basin and a volcanic region in central Germany, respectively.
} 


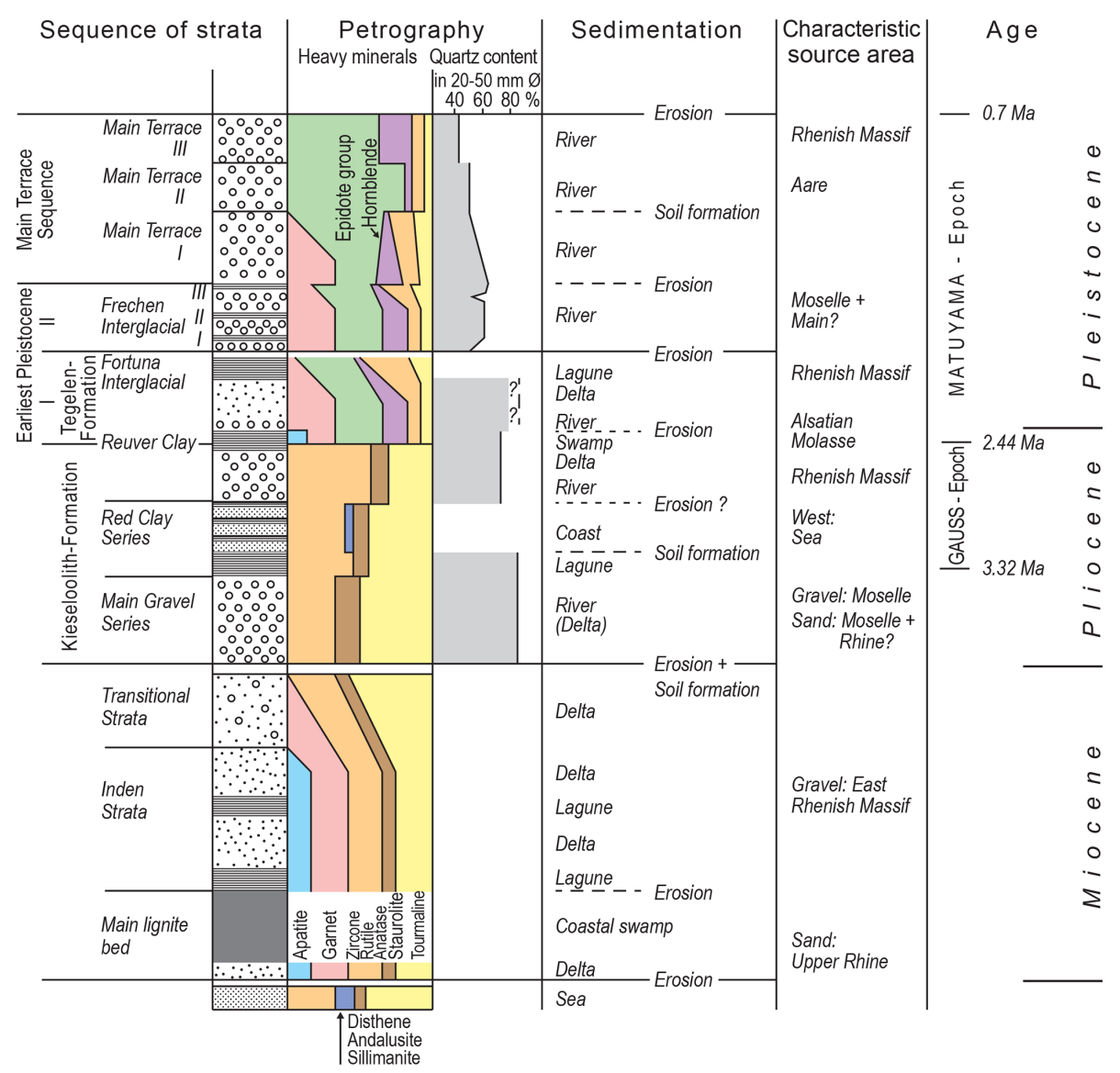

Figure 1. Late Tertiary and early Quaternary stratigraphic sequence of the Lower Rhine Basin with information on the characteristic petrographic and sedimentological features.

In the following period of the Red Clay Series ("Rotton"), a long-lasting lagoonal depositional facies prevailed in the central parts of the Lower Rhine Basin, leading to the formation of the Main Red Clay Series ("Hauptrotton") (Fig. 2). This clay horizon is overprinted by a thick subaerial soil formation, which documents a pause in sedimentation even in the deepest parts of the basin. In the marginal parts of the basin, however, coarse gravel accumulation continued during the formation of the Main Red Clay Series (Boenigk, 1978b), suggesting the operation of a braided river system in a semi-arid climate during this time. For the younger Red Clay Series, a marine transgression into the middle Lower Rhine Basin is reconstructed, also evidenced by coastal sediments in the Fortuna open cast mine (Fig. 2).

During this time, the southern Lower Rhine Basin was dominated by fine-clastic sedimentation including various peat horizons. The flora of this period, the Brunssumian, indicates a warm temperate climate (Zagwijn, 1960). A positionstable meandering river system prevailed, which explains the low proportion of fluviatile deposits in the recorded sediments at this time.
The "Rotton" (red clay series) is overlain by a horizon containing coarse gravel which is part of the "Kieseloolith Formation" $"$. Its deposition in the southern portion of the basin was associated by a precursor system of the River Rhine. Into the western portion of the basin material was delivered by the River Meuse (Fig. 2, layer 10). The resulting gravel units are very coarse including large blocks but also includes a higher proportion of soft components than is observed in the gravel of the Main Gravel Series (Fig. 1).

Based on their petrographic composition, the gravel delivered by the River Rhine represents a transitional type between the typical gravel of the "Kieseloolith Formation", forming the Main Gravel Series, and the gravel of the Pleistocene Rhine facies. Devonian and reworked Tertiary rocks sourced from the area of the Rhenish Massif dominate in both the sand and gravel fractions. The transitional position of this gravel body becomes particularly clear in the area where sediments of the River Meuse predominate. A subdivision of the gravels into Pliocene or Pleistocene deposits, based on petrographic composition or grain size, however, is

\footnotetext{
${ }^{4} \mathrm{TN}$ : the name refers to a formation characterised by the occurrence of silicified oolithic limestone gravel.
} 


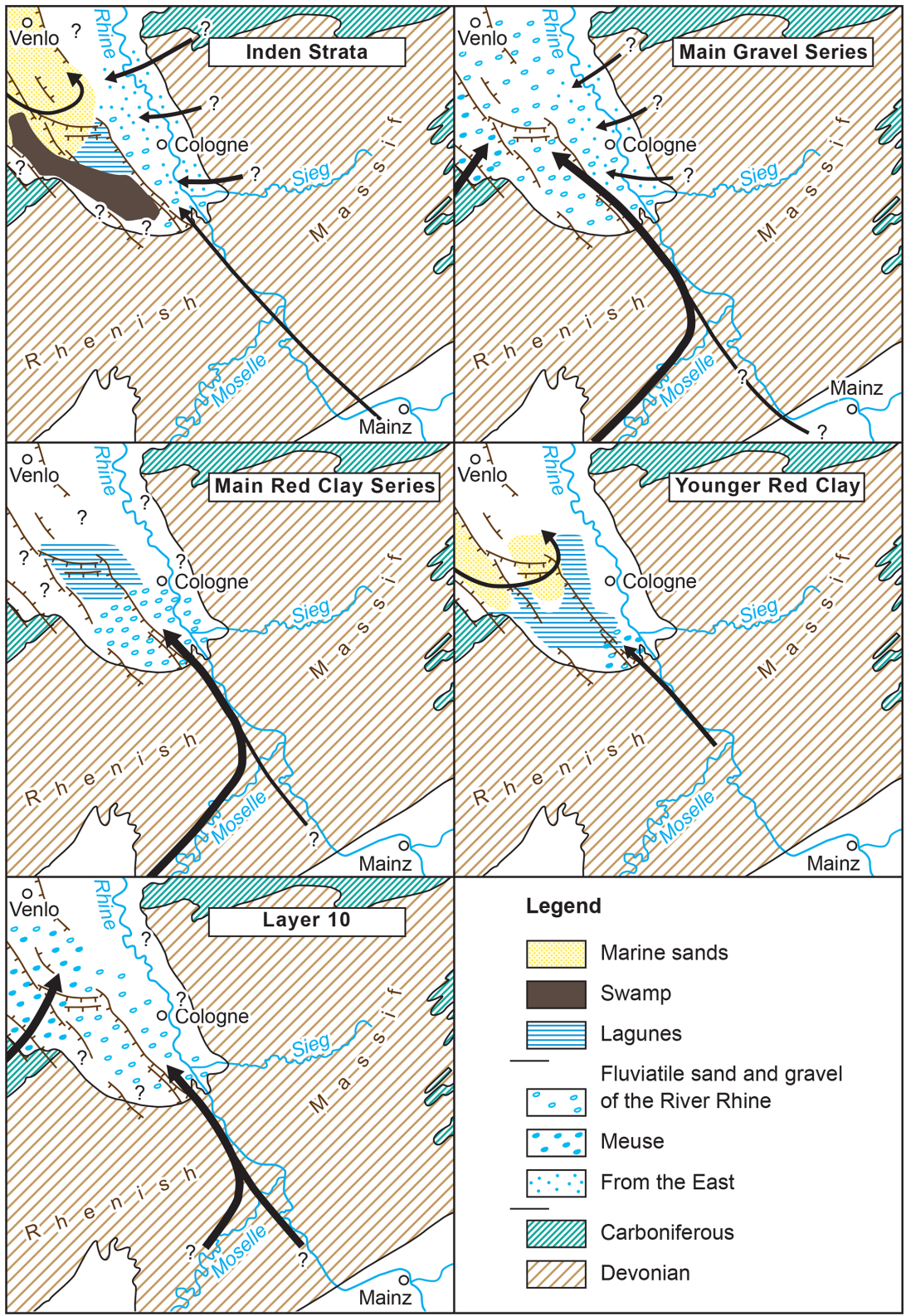

Figure 2. Sediment supply to the Lower Rhine Basin during the late Miocene and Pliocene periods.

not possible at present. The gravels indicate strongly fluctuating river flows with extreme floods and an abundant supply of debris. Floristic evidence (Zagwijn, 1960) indicates a cool and dry climate, so that cool semi-arid conditions with a braided river regime are assumed to have prevailed during this period and following the Brunssumian. This coarse clastic sedimentation is again followed by the accumulation of clay and sand containing numerous peat horizons, which is widespread in the Lower Rhine Basin. This Reuver Series represents a formerly marshy landscape with dense vegetation. At the same time fluvial deposition receded strongly. Based on the flora (Zagwijn, 1960), the climate is described as humid-moderate, but sedimentological and palaeontolog- ical investigations show that strong fluctuations in both temperature and humidity must have occurred during the Reuverian (Boenigk, 1978b).

In the Reuver Clay, the most striking change in the petrographic composition of the Pliocene sediments in the Lower Rhine Basin takes place. It is attributed to an extension of the Rhine catchment area into the area of the Alsace Molasse (Boenigk, 1976). The "Kieseloolith Formation" is replaced by the Tiglian Formation ("Tegelen Formation"). Palaeomagnetic studies (Boenigk et al., 1974) show that this change occurred at the turn of the normally magnetised Gauss epoch to the reversely magnetised Matuyama epoch, 2.44 million years ago. This also gives a good indication of the age of 


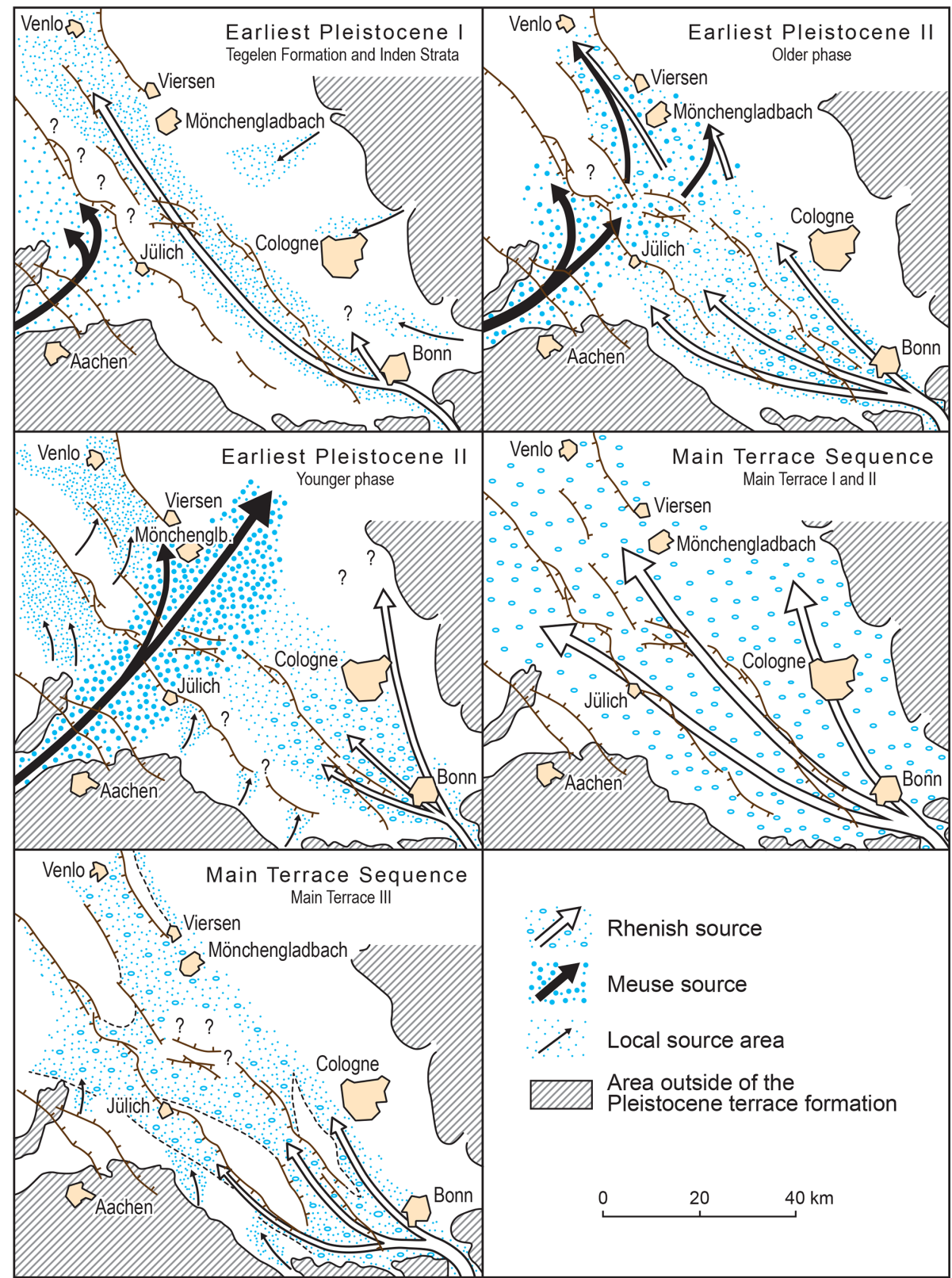

Figure 3. Directional patterns of sedimentation in the Lower Rhine Basin during the early Quaternary based on heavy mineral content and gravel analyses by Musa (1973) and Schnütgen (1974).

the Tertiary/Quaternary boundary: it can only be somewhat younger, since the transition to the Pleistocene is recorded in the Reuver Clay (Zagwijn, 1960; Boenigk et al., 1974).

\section{Early Quaternary}

The sediments overlying the Reuver Clay belong to the Pleistocene. Sedimentologically, however, the facies distribution from the Pliocene continues into the Early Pleistocene I (Fig. 1). Above a relatively little known coarse clastic horizon, which is formed in the facies of the Rhein-influenced
Tegelen Formation in the area of the Erft Block and the Venlo Graben, and in the facies of the "Jülicher-Schichten" (Jülich strata), supplied by the River Meuse, in the area of the Rur Block (Fig. 3) (Breddin, 1955), lie thick clay strata with a Pleistocene interglacial-age flora. In the Venlo Graben this is the well-known Tegelen Clay, the type sediment of the Tiglium, and in the area of the Erft-Scholle the so-called "Layer 13" (Schneider and Thiele, 1965). Since a secure correlation is not possible at present, Layer 13 should be given the local name Fortuna Interglacial Period, after the open cast mine of the "Rheinische Braunkohlenwerke AG", where 
this horizon is well exposed in the west wall ( $34 \mathrm{ma.s.1}$ ) (Boenigk, 1978b). At this time, the Lower Rhine Basin was a coastal marshland with meandering rivers. Towards the end of this interglacial period, the supply of long-distance material decreased, and sediment supply from the Rhenish Massif dominated (Boenigk, 1978b, 19795).

The sediments of the Early Pleistocene I are truncated by a distinct unconformity. In addition to the tectonic activity, which led to the rearrangement of the river system in the Lower Rhine Basin, a significant cooling must also have occurred during this period, as evidenced by a strongly reduced faunal content in the overlying sediments. With the Early Pleistocene II, the period of exclusively fluvial-lacustrine facies began in the Lower Rhine Basin, which continues to this day.

The characteristic alternation of glacial and interglacial intervals during the Pleistocene are primarily represented by deposits of the glacial phases i.e. gravelly sediments of braided river systems, while the interglacial phases with their meandering rivers are only preserved in local still-water sediments and isolated soil horizons. Deposits of the interglacial periods, which were already poorly represented, were usually further eliminated by erosion at the beginning of the following glacial period and are thus strongly underrepresented in the record.

In the Early Pleistocene II, the River Rhine deposited coarse gravels in the south of the Lower Rhine Basin (Fig. 3), which at least partly indicate a braided river system. The material was essentially supplied via the present-day tributaries of the Rhine, the Rivers Moselle and Main. The middle part of the Lower Rhine Basin is characterised by coarse gravels of the River Meuse, which crossed the basin from southwest to northeast and having pushed the Rhine far to the east. In the northern parts of the basin, a local redeposition of older sediments took place (Fig. 3, Early Pleistocene II, younger section). These deposits are known in the Netherlands as the Kedichem Formation.

In the Frechen open cast mine operated by the "Rheinische Braunkohlenwerke AG", interglacial clays are intercalated with peat horizens within the strata of the Early Pleistocene II, which are referred to as Frechen Interglacials I to III $^{6}$ until a reliable assignment to the Dutch classification becomes possible.

With the change from the Early Pleistocene II to the Main Terrace Sequence ("Hauptterrassenfolge"), the drainage system in the Lower Rhine Basin was once again reshaped by a phase of tectonic activity. The River Meuse was finally pushed out of the Lower Rhine Basin and the entire basin

${ }^{5} \mathrm{TN}$ : In the original article, this paper is cited as Boenigk (1978c) but publication was actually delayed until 1979.

${ }^{6}$ (This is given as foot note in the original text): The name was determined by agreement at the Department of Ice Age Research, Cologne. was filled up with thick coarse gravel of the Rhine. The braided glacial period river system dominated the basin from the "Bergische Randhöhen" in the east to the Eifel in the southwest (Fig. 3, Main Terrace I and II). Warmer sections with meandering river courses can only be detected via few interbedded soil horizons.

Towards the end of the Main Terrace Sequence (Main Terrace III), which coincides with the switch of the Earth's magnetic field from the reversely magnetised Matuyama epoch to the normally magnetised Brunhes epoch, at 700000 years, another significant tectonic phase becomes noticeable. The deposits of the Main Terrace III do no longer occur across the entire basin, but are restricted to the subsidence areas (Fig. 3 cf. also Schnütgen, 1974). Areas of relative uplift such as the Brüggen-Erkelenzer Horst, the Lommersumer Horst, parts of the Ville and the Rur Block margin, were no longer affected by gravel deposition. The sediments indicate a dominance of deposition sourced from the Rhenish Massif. More distally sourced components from areas to the south are now completely repressed. Besides tectonic factors, the change in material composition may also be climatically influenced. For the first time, there are widespread signs in the Main Terrace III for a glacial period including permafrost indicators in the Lower Rhine Basin and the Rhenish Massif, conditions which make an increased supply of debris from the low mountain ranges probable.

With the Main Terrace IV, the Rhine leaves the western Lower Rhine Basin as a result of continuing tectonic movements and, from the beginning of the Middle Terrace period until today, the Rhine is routed east of the Ville, whose eastern slope was generated by erosional activity of the River Rhine during this period. The western Lower Rhine Basin has since been drained by small streams such as the Erft, Rur and Nette.

Review statement. This paper was edited by Frank Preusser.

\section{References}

Boenigk, W.: Schwermineraluntersuchungen zur Entwicklung des Rheinsystems, E\&G Quaternary Sci. J, 27, 202, 1976.

Boenigk, W.: Schwermineralassoziationen im Grenzbereich Tertiär/Quartär der Erft-Scholle (Niederrheinische Bucht), Fortschritte in der Geologie von Rheinland und Westfalen, 28, 123-133, 1978a.

Boenigk, W.: Gliederung der altquartären Ablagerungen in der linksrheinischen Niederrheinischen Bucht, Fortschritte in der Geologie von Rheinland und Westfalen, 28, 135-212, 1978 b.

Boenigk, W.: Die Gliederung der tertiären BraunkohleDeckschichten in der Ville (Niederrheinische Bucht), Fortschritte in der Geologie von Rheinland und Westfalen, 29, 193-263, 1979. 
Boenigk, W. and Brinkmann, K.: Petrographische Untersuchungen gibbsitführender Tertiär Sedimente bei Schwerfen (Niederrheinische Bucht), N. Jb. Geol. Palaeont. Mh., 253-265, 1976.

Boenigk, W., Von der Brelie, G., Brunnacker, K., Koci, A., Schlickum, W. R., and Strauch, F.: Zur Pliozän-PleistozänGrenze im Bereich der Ville (Niederrheinische Bucht), Newsl. Stratigr., 3, 219-241, 1974.

Breddin, H.: Die Feuersteingerölle im Niederrheinischen Tertiär, ein Beweis für die paralische Natur der Braunkohlenflöze, Centralblatt für Mineralogie, Geologie und Paläontologie, 8, 395404, 1932.

Breddin, H.: Die Gliederung der altdiluvialen Hauptterrasse von Rhein und Maas in der Niederrheinischen Bucht, Der Niederrhein, 22, 76-79, 1955.

Kurtz, E.: Die Leitgesteine der vorpliozänen und pliozänen Flußablagerungen an der Mosel und am Südrande der Kölner Bucht, Verhandlungen des Naturhistorischen Vereines der Preussischen Rheinlande, 83, 97-159, 1926.

Kurtz, E.: Die Spuren einer oberoligozänen Mosel von Trier bis zur Kölner Bucht, Zeitschrift der Deutschen Geologischen Gesellschaft, 83, 39-58, 1932.

Musa, I.: Rhein- und Eifelschüttungen im Süden der Niederrheinischen Bucht, Sonderveröff. Geol. Inst. Univ. Köln, Köln, 23, 151 pp., 1973.

Quitzow, H. W.: Die Terrassengliederung im niederrheinischen Tieflande, Geol. Mijnbouw, 18, 357-373, 1956.
Schneider, H. and Thiele, S.: Geohydrologie des Erftgebietes, Ministerium für Ernährung, Landwirtschaft und Forsten des Landes Nordrhein-Westfalen, Düsseldorf, 185 pp., 1965.

Schnütgen, A.: Die Hauptterrassenfolge am linken Niederrhein aufgrund der Schotterpetrographie, 1st edn., Forschungsberichte des Landes Nordrhein-Westfalen, 2399, VS Verlag für Sozialwissenschaften, Opladen, Germany, 150 pp., https://doi.org/10.1007/978-3-322-98839-3, 1974.

Sindowski, K.-H.: Studien zur Stratigraphie und Paläogeographie des Tertiärs der südlichen Niederrheinischen Bucht, Neues Jb. Miner. Abh., 82, 415-484, 1939.

Von der Brelie, G.: Zur pollenstratigraphischen Gliederung des Pliozäns in der Niederrheinischen Bucht, Fortschritte in der Geologie von Rheinland und Westfalen, 4, 27-54, 1959.

Von der Brelie, G.: Zur mikrofloristischen Schichtengliederung im rheinischen Braunkohlenrevier, Fortschritte in der Geologie von Rheinland und Westfalen, 16, 85-102, 1968.

Weyland, H.: Beiträge zur Kenntnis der rheinischen Tertiärflora. I. Floren aus den Kieseloolith- und Braunkohlenschichten der niederrheinischen Bucht, Abhandlungen der Preußischen Geologischen Landesanstalt, 161, 122 pp., 1934.

Zagwijn, W. H.: Aspects of the Pliocene and Early Pleistocene vegetation in the Netherlands, Mededelingen van de Geologische Stichting, serie C-III-1, 5, 5-78, 1960. 